J. Perinat. Med. 16 (1988) 381

\section{Computerized and telemetric management of diabetic pregnancy in Cambridge}

\author{
Huw Alban Davies', Kevin J. Dalton², John D. A. Clark ${ }^{1}$, Philip Robarts ${ }^{2}$, David \\ Juett $^{3}$, and Owen M. Edwards ${ }^{1}$ \\ ${ }^{1}$ Dept. of Diabetes \& Endocrinology, Addenbrooke's Hospital, Cambridge \\ ${ }^{2}$ Perinatal Research Group, Dept. of Obstetrics \& Gynaecology, University of \\ Cambridge, Rosie Maternity Hospital, Cambridge \\ ${ }^{3}$ Dept. of Medical Physics, Addenbrooke's Hospital, Cambridge
}

\section{Introduction}

Diabetic pregnancy presents a remarkable clinical challenge. On the one hand, if diabetic pregnancies are managed well, then their complication rates are similar to those in the non-diabetic pregnant population $[8,10]$. On the other hand, if diabetic pregnancies are poorly controlled, then the incidence of major congenital abnormality [14] may reach as high as $22 \%$ and the perinatal mortality [10] may reach as high as $24 \%$ (sic). Evidence from KARLSSON's group [10] suggests that perinatal mortality is minimized when the average blood glucose level in the third trimester is $\leq 5.5$ $\mathrm{mmol} / \mathrm{l}$.

Self-monitoring of blood glucose at home spares the need for routine hospitalization for the control of diabetes in pregnancy, which in former years was commonly from 25 weeks to term. However, the policy of home management puts the responsibility of care firmly on the woman herself. The stress imposed on patients by the need for excellent diabetic control during pregnancy cannot be underestimated, and it is perhaps not surprising that their glucose measurements are not always reported reliably. Indeed, when LANGER and MAZZE [13] gave their pregnant diabetics blood glucose meters fitted clandestinely with a memory chip they found that $97 \%$ (sic) of such patients logged incorrect glucose values from time to time.

Until fairly recently, close monitoring of diabetic pregnancy has necessitated frequent attendance at the hospital clinic, or even admission to hospital.

\section{Curriculum vitae}

After degrees in philosophy and psychology Huw ALBAN DAVIES MA., DM., MRCP. qualified in medicine at Oxford University in 1974. His DM thesis was entitled Agina and Oesophageal Disease'. Present research interests include the treatment of diabetes in pregnancy; the community approach to diabetic care; the treatment of obesity with very low calorie diets; and a trial of an HMG CoA reductase inhibitor in hyperlipidaemia. Present position is Consultant Diabetologist at West Hill Hospital Dartford, Kent.

However, an alternative approach is to transmit the glucose measurements from the pregnant woman's home into the maternity unit by means of a telemetric link over the public telephone network. There are three obstetrical precedents for this, as fetal heart rate $[2,3]$, uterine contractions [11], and maternal blood pressure [4] have all been monitored telemetrically from home. Computer technology is also becoming used more widely by diabetologists $[5,6]$. Because of this, and because of the large number of blood glucose measurements which need to be recorded and then subsequently analysed, the use of computers appears to be particularly appropriate in the home management of diabetic pregnancy [1]. 
Here we present our results using the Ames MGlucometer, a portable blood glucose meter which is capable of timing and memorizing 440 measurements which can then be sent over the public telephone network for analysis.

\section{Methods}

\subsection{The patients:}

We studied 17 consecutive pregnancies in 16 insulin dependent diabetic women who were referred to the Diabetic Antenatal Clinic of the Rosie Maternity Hospital in Cambridge, and who delivered between August 1985 and April 1987; one woman completed two pregnancies during the study period. Our series includes only women who were managed under the joint care of KJD and OME, and it does not include those pregnant diabetics who were managed along more traditional lines in other Consultants' clinics in the Rosie. No gestational diabetics are included in the present study.

\subsection{Diabetic management}

\subsubsection{Blood glucose measurement}

All the women measured their own capillary blood glucose levels using a portable reflectance meter. They used the Ames Memory Glucometer model 5581 with Dextrostix test strips until January 1987, and changed to the Ames Glucometer- $M$ model 5607 with Glucostix test strips thereafter. (Both models are hereafter abbreviated to AMG). All but one of these women were already measuring their own blood glucose levels before the index pregnancy, but we always rechecked their technique. The memory capability of the glucose meter was explained and women were shown how to use their meter to retrieve previous values for inspection, as well as the average of all recorded readings. Initially, they were all asked to measure their fasting, 2-hour post-prandial and bedtime blood glucose levels (ie. 5 measurements per day). However, if control was stable fewer measurements might be made; conversely if control was unstable, then more frequent measurements would be made.

We set a specific target for average blood glucose of $5.5 \mathrm{mmol} / \mathrm{l}$ (see introduction). We also set a target range for their blood glucose levels of 3.5 to $7 \mathrm{mmol} / 1$, which was widened to 3.5 to 10.0 $\mathrm{mmol} / 1$ if frequent hypoglycaemic episodes occurred. They were encouraged to make minor ad- justments to their own insulin dosage (ie. \pm 2 units/dose) to keep within this range on a day to day basis. We usually evaluated their blood glucose levels and insulin requirements every two weeks, unless control was unstable when they were reviewed on a weekly or even a daily basis. Haemoglobin A1 levels were measured at four- to sixweekly intervals throughout the pregnancy using an ion exchange chromatographic technique (from Boehringer). The normal non-pregnant range of $\mathrm{HbA1}$ for our laboratory is $5.5 \%$ to $8.5 \%$.

\subsubsection{Insulins}

Before pregnancy, women had been treated with a variety of insulin regimes. If these regimes proved inadequate, despite making dose adjustments, the women were converted to a multiple injection regime, with ultralente or isophane insulin once at night, and pre-prandial soluble insulin. Their partners were instructed in the use of intramuscular glucagon in the event of severe hypoglycaemia.

\subsubsection{Clinic visits}

At all clinic visits, each $A M G$ was connected to an IBM PC-XT or Tandon PCX microcomputer running under Glucofacts software (Ames Division, Miles Laboratories). This analysed the blood glucose results since the patient's last attendance, and displayed the analysis graphically (figures 1 and 2).

\subsubsection{Admission to hospital}

Our patients were not admitted into hospital as a routine at any particular stage of pregnancy, although brief admissions were occasionally required for various obstetrical or diabetic reasons. When in hospital patients continued to monitor blood glucose with their own AMG.

\subsubsection{Telemetry}

Glucose telemetry was performed successfully by six of the women, all of whom were using an AMG Model 5581. They were provided with a telephonic modem (Miracle Technology, WS 2000) which interfaced with their AMG, whose output data had first to be changed from TTL format to RS232 format. This system permitted their blood glucose results to be sent over the telephone network and into the computer in the Diabetic Antenatal Clinic. On receipt of such telephonic data, the obstetrician and diabetologist jointly reviewed 

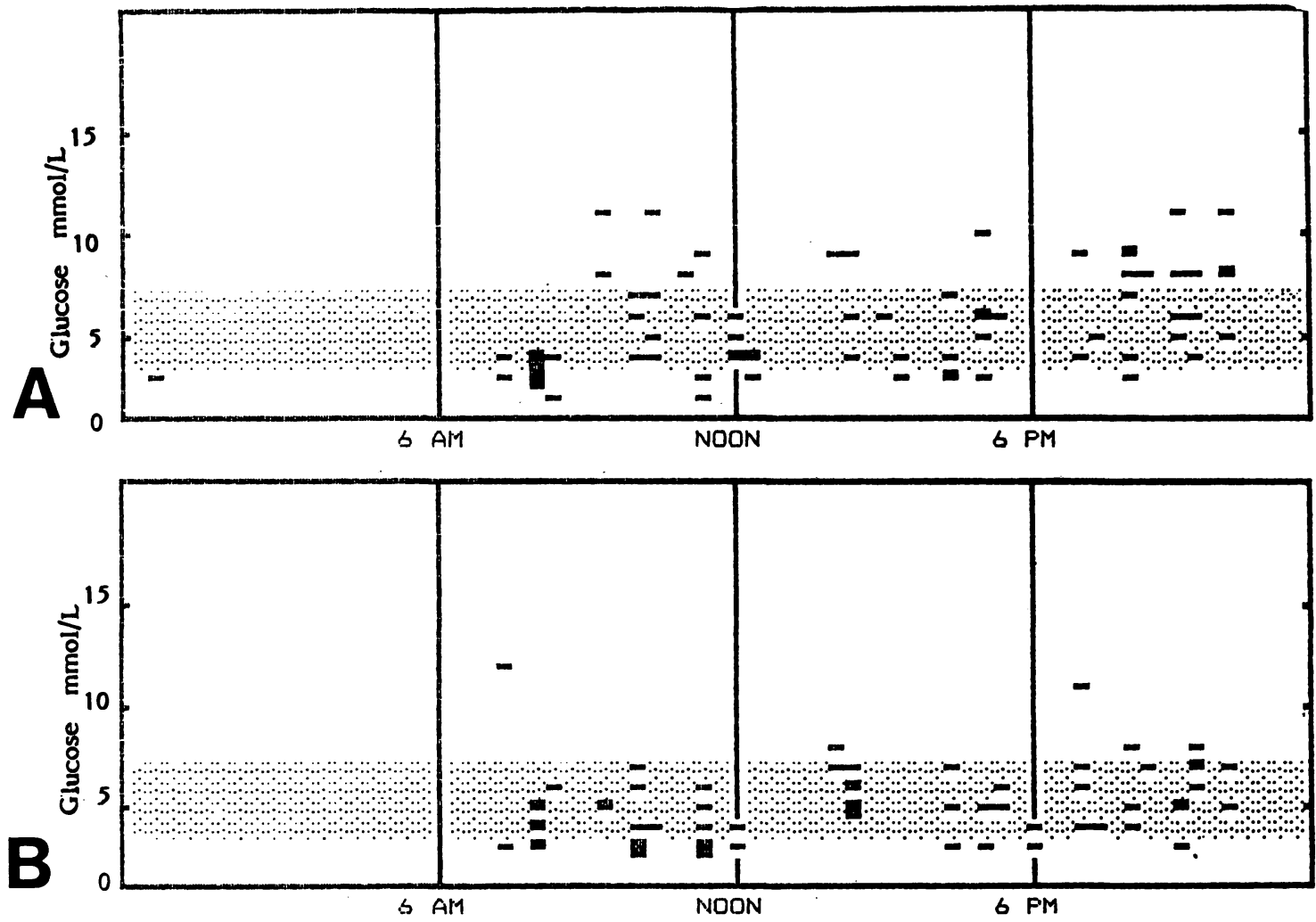

Figure 1. Blood glucose data plotted against time ( $24 \mathrm{~h}$ cycle) for two epochs of two weeks each. The blood glucose target range of 3.5 to $7 \mathrm{mmol} / 1$ is shaded.

A: Many blood glucose results were above the target range, particularly two hours after breakfast and after the evening meal. This patient was advised to lengthen her interval between insulin and food from 15 to 30 minutes. No change was made in insulin dosage.

B: Following this advice, post-prandial hyperglycaemia was avoided almost completely over the next two weeks.

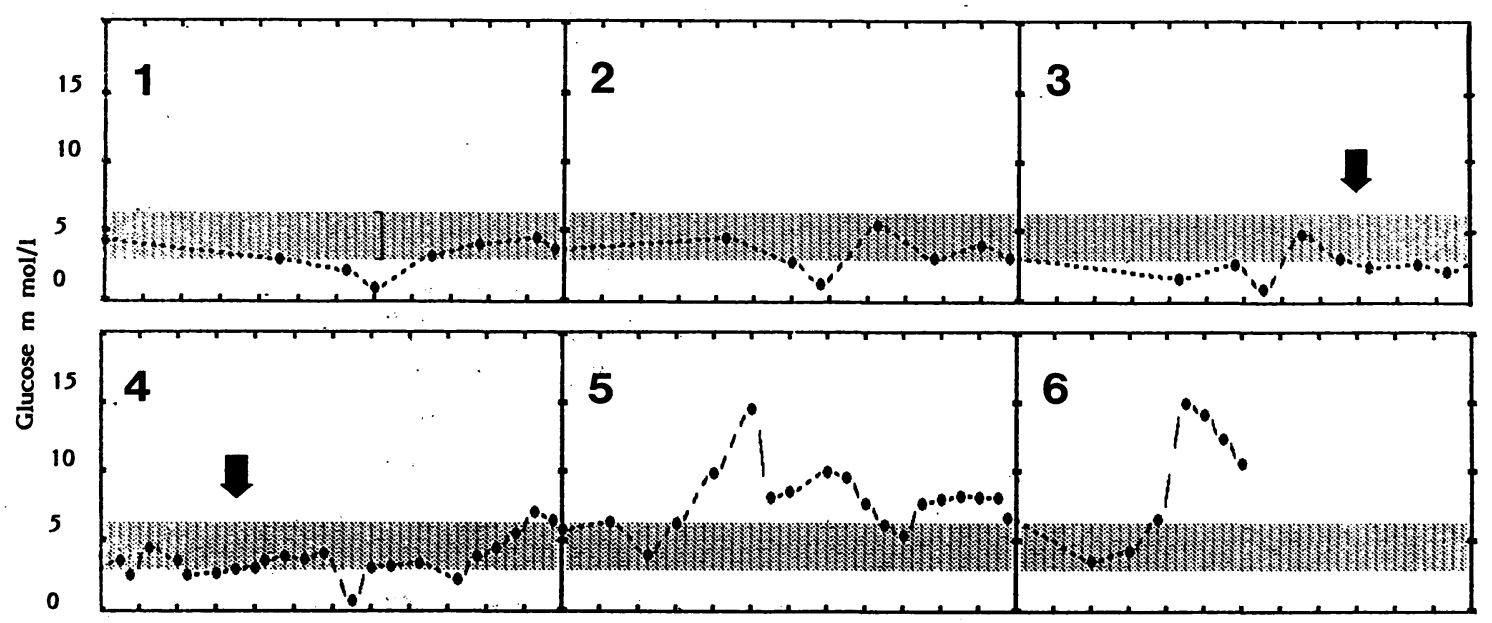

Figure 2. Diary record of bloọd glucose levels against time of day over six consecutive days. During day 3 labour commenced (arrow), and the frequency of blood glucose measurement was increased as described in the text. Delivery occurred during day 4 (arrow). Over the next two days, this particular patient's control of blood glucose was not ideal, as is easily seen. 
the analysis, and then telephoned each patient to discuss any alterations in management.

\subsubsection{Obstetrical Management}

Gestational age was calculated from the last menstrual period, and confirmed ultrasonically by the measurement of biparietal diameter at 18 weeks gestation. From 24 weeks onwards, ultrasonic measurements of biparietal diameter and of abdominal circumference were repeated at monthly intervals to check that growth was satisfactory. All pregnancies were allowed to progress to term, unless there was an obstetrical or a diabetic reason for intervention earlier, or unless Caesarean section was planned (usually in the 38th week of gestation). Amniocentesis to assess fetal lung maturity was not performed on any of the patients.

During labour or at Caesarean section, all patients received an infusion of $5 \%$ dextrose solution (with $40 \mathrm{mmol} \mathrm{KCl}$ added to each litre), and an infusion of soluble insulin, with dosage adjusted according to a sliding scale, based on hourly Dextrostix or Glucostix blood glucose readings. Labour and delivery were conducted according to standard obstetrical practice, and the fetal heart rate and uterine contractions were monitored throughout. After delivery, the infusions of $5 \%$ dextrose and of soluble insulin were discontinued as soon as patients were able to resume eating. Whilst the patient remained in hospital (usually for seven days after delivery), insulin requirements were reviewed carefully. On discharge patients were advised to continue adjusting their insulin dosages themselves whenever necessary, and they were reviewed back in the combined Clinic six weeks after delivery.

\section{Results}

\subsection{Initial Assessment}

The mean gestational age when first seen in the Clinic was $12.2 \pm 5.5$ (SD) weeks. Ten of the women were primigravid; the other 6 had previously had one pregnancy each, with two macrosomic babies and a Caesarean section rate of $33 \%$. Their mean age was $27.8 \pm 3.6$ years, and the mean duration of their diabetes was $11.1 \pm 6.8$ years. Diabetic complications were present in four women, all of whom had background retinopathy; one also had cataracts. Pre-conceptional HbA1 values were available for 13 out of 17 pregnancies: average $\mathrm{HbAl}=8.5 \% \pm 1.3 \%$. Control had been particularly good in eight of these women, who had HbA1's below $8.5 \%$. (Our normal range $=5.5 \%$ to $8.5 \%$.)

\subsection{Diabetic control through pregnancy}

During all 17 pregnancies, an average of $4.5 \pm 1.2$ blood glucose measurements were carried out each day. Nine women performed fewer than the recommended five measurements per day; this was deliberate policy for five women because control was optimal (average blood sugar $<5.5 \mathrm{mmol} / \mathrm{l}$ ), but in four women compliance was not ideal. These poorly compliant women carried out an average of only 3.0 readings per day (range 2.5 to 3.4 readings per day for each women), and their average blood glucose level in the third trimester was $7.1 \pm 0.7 \mathrm{mmol} / \mathrm{l}$. In the more compliant women, on the other hand, the average third trimester blood glucose level was only $5.2 \pm 0.6$ $\mathrm{mmol} / \mathrm{l}(\mathrm{p}<0.01)$.

Average capillary blood glucose levels in the group as a whole fell from $6.4 \pm 0.9 \mathrm{mmol} / 1$ in the first trimester, to $6.1 \pm 1.2 \mathrm{mmol} / 1$ in the second trimester, and then to $5.6 \pm 1.0 \mathrm{mmol} / 1$ in the third trimester (not significant). There was a corresponding change of $\mathrm{HbA} 1$ from $8.0 \pm 1.5 \%$ in the first trimester, to $6.5+-0.8 \%$ in the second trimester, and to $6.2 \pm 0.4 \%$ in the third trimester ( $p<0.002$ for 1 st to 2 nd trimester; $p<0.001$ for 1st to 3rd trimester). During the third trimester, an average blood glucose at or below the optimal $5.5 \mathrm{mmol} / 1$ was achieved in 12 of the 17 pregnancies.

Episodes of hypoglycaemia were relatively common, and all women had occasional mild to moderate reactions. Three women had severe hypoglycaemia reactions with reduced consciousness, and they required intramuscular glucagon or intravenous glucose. Six women were hospitalised on 14 occasions: on five of these it was simply to stabilise their diabetic control; four admissions were principally for obstetrical reasons (hypertension in two, urinary infection in one and possible premature rupture of membranes in another); and the remaining five admissions were for vomiting which needed careful monitoring to avoid hypoglycaemia. However, one particular patient had severe social problems which were partly responsible for four of her five admissions. During the pregnancy, insulin treatment was reviewed every one or two weeks and the dosage was increased from an average of $43 \pm 13$ units per day before pregnancy to $86 \pm 28$ units per day at term. 


\subsection{Home telemetry of blood glucose levels}

Successful telemetric transmissions of blood glucose data were made from the homes of six women whose telephones were fitted with a plug-in connection, on 42 occasions. All of these women were using the Model 5581 AMG. Three other women would have liked home telemetry, but their telephone connections were of the old-fashioned 'fixed' type and therefore unsuitable for our purposes. An attempt at telemetry was made from another woman's home, but this was unsuccessful because of the poor quality of the telephone line, which had frequent loud crackles; other telephone lines from this remote village had similar problems.

\subsection{Eventual outcome}

All women delivered healthy babies in good condition at $38.9 \pm 1.3$ weeks gestation on average (range: 37-41 weeks). Induction of labour was carried out at the end of 9 of the 17 pregnancies, and Caesarean section was planned in three others (two for breech, and one because of a previous Caesarean section). The remaining five women went into labour spontaneously. Thus, of the 14 women in whom vaginal delivery was planned, this was achieved in all except one $(93 \%)$. Forceps delivery was needed by six $(46 \%)$ of the women who delivered vaginally: five for delay in the second stage of labour (two of whom needed rotational forceps), and one for fetal distress. One Caesarean section was performed for failed induction, the original indication for which had been spontaneous rupture of membranes at 38 weeks gestation without ensuing contractions.

There were no congenital birth defects, but two babies were macrosomic, one $4.35 \mathrm{Kg}$ at 39 weeks, and the other $5.27 \mathrm{Kg}$ at 37 weeks, both above the 95th centile [17]. The two mothers had average third trimester blood glucose levels of 5.2 and 4.4 $\mathrm{mmol} / 1$, and $\mathrm{HbA} 1$ values of 6.5 and $6.4 \%$ respectively. In the babies, blood glucose levels were measured within the first hour after delivery, and thereafter four hourly for 36 hours, using Dextrostix strips. Only two babies had hypoglycaemic episodes, each on a single occasion. One infant had mild jaundice, and another had mild respiratory distress syndrome which required no treatment. In contrast, the two macrosomic infants had no problems at all in the neonatal period.

\subsection{In the puerperium}

At discharge from hospital the average insulin dosage was $32 \pm 11$ units per day, and at the 6 week-natal clinic appointment it was $36 \pm 13$ units per day.

\subsection{Patient satisfaction}

In 14 of our 17 pregnancies, the mother said that our computerized implementation of the AMG system increased her confidence, both in our management and also in her own control of diabetes during the pregnancy. None of the 16 women in our study objected in any way to the use of a computer in their diabetic management during pregnancy.

\section{Discussion}

It is now generally accepted that the closer metabolic control approaches euglycaemia, the better the outcome for a diabetic pregnancy. With our computerized system for managing diabetic pregnancy we achieved our third trimester target for average blood glucose values of $\leq 5.5 \mathrm{mmol} / 1$ in 12 out of 17 pregnancies. The overall outcome of pregnancy in our series was good, with no significant maternal or fetal complications. Our overall Caesarean section rate was only $23 \%$, which compares favourably with a rate of $66 \%$ in HELLER et al's series [9], although DRURY [7] did achieve a rate of only $20 \%$. In our study, neonatal complications were uncommon and none was serious. The incidence of neonatal hypoglycaemia was $12 \%$, which is similar to that in other series [9, 15]. Interestingly, we have been able to confirm the finding of KNIGHT et al [12] that fetal macrosomia is not necessarily associated with poor diabetic control in the mothers. Both of our mothers with macrosomic babies had good diabetic control in the third trimester, with near-normal average blood glucose levels, and HbA1 values at the lower end of the normal range. Our numbers do not yet permit any conclusions to be drawn on the impact of our computerized management protocol on perinatal death rates or on congenital malformation rates. Indeed, any significant impact on the malformation rate would be unlikely, unless tight diabetic control had been introduced pre-conceptionally [8]. 
The Ames Memory Glucometer system produces an accurate and complete record of timed readings of blood glucose carried out by the patient herself whilst going about her everyday life, while the analysis provided by the clinic-based microcomputer helps the clinician in his assessment of control and his diabetic management. The AMG system also has an educational role to play by providing a very clear demonstration of glycaemic trends, so that the influence on blood glucose of diet, mealtimes, exercise, insulin dose and the timing of insulin injections can all be discussed. Used in this way, our computerized implementation of the AMG system increased the patients' confidence in our management in 14 out of 17 pregnancies. The telemetry service which operated during the present study was in some ways a pilot scheme, though a routine service would undoubtedly lead to very substantial benefits both in terms of cost and of time. We have shown that telemetric relay of blood glucose data is practical and that 'telemetric clinics' can be integrated with conventional ones, with the full cooperation of the diabetic women themselves.

When diabetic control is very tight, there is an inevitable risk of hypoglycaemia, and pregnancy is no exception to this. All of our patients experienced more frequent episodes of hypoglycaemia than when they were not pregnant, and three of the women had severe hypoglycaemic reactions which required intravenous glucose or intramuscular glucagon. We therefore consider it essential that the spouses of all pregnant diabetic women should be instructed in the use of glucagon, so that the blood glucose level can be restored promptly if needs be. However, although the experience of hypoglycaemia is certainly unpleasant, it is by no means uniformly accepted that its consequences are any more serious in pregnancy than at other times. For example, in a large series of 600 diabetic pregnancies, DRURY et al [7] found no association between maternal hypoglycaemia and intrauterine fetal death.

The success of the home-management approach depends on the pregnant women carrying out frequent blood glucose measurements on herself and our own results show that control was worse in those women who failed to follow our recommendations about the frequency of self-monitoring. Success also depends on the accuracy of these measurements and on the reliability with which they are reported. Certainly any inaccuracy due to poor technique with the reflectance meter should be looked for and corrected, though from Langer and Mazze's, and O'Connell et al's work $[13,16]$ it seems clear that unreliable reporting of blood glucose measurements poses a greater problem. A particular advantage of the AMG system is that reporting is reliable, and patients should not see it as a 'spy' so long as its positive advantages are stressed. It is our own practice to have the computer in the consulting room itself. This enables our patients to see the analysis for themselves and we encourage their comments, taking full advantage of the AMG's educational potential. Used in this way computers facilitate the intensive care of diabetic pregnancy, and home telemetry promises to make such intensive care more convenient and also more economical.

\begin{abstract}
In order to optimize the quality of our care, we have used the Ames Memory Glucometer in our computerized management of 17 insulin-dependent diabetic pregnancies. Patients measured their own blood glucose levels on $4.5 \pm 1.2$ (SD) occasions per day, and six of them transmitted their blood glucose measurements telemetrically from home into a hospital-based computer on a total of 42 occasions. We achieved near-optimal blood glucose levels and normal HbA1 levels throughout most of these 17 pregnancies. Average blood glucose levels were $6.4 \pm 0.9 \mathrm{mmol} / 1$ in the first, $5.9 \pm 1.2 \mathrm{mmol} / 1 \mathrm{in}$ the second, $5.4 \pm 1.0 \mathrm{mmol} / 1$ in the third trimester.
\end{abstract}

Corresponding values for $\mathrm{HbA1}$ were $8.0 \pm 1.5 \%, 6.5$ $\pm 0.8 \%$, and $6.2 \pm 0.4 \%$. Average insulin requirement doubled during pregnancy, but fell to $74 \%$ of the prepregnancy dosage by one week after delivery. The average gestational age at delivery was $38.9 \pm 1.3$ weeks, and we had no perinatal deaths. Two of the babies were macrosomic, even though their mothers had good diabetic control. Four patients were delivered by Caesarean section. However we achieved a vaginal delivery in $93 \%$ of those in whom it was planned. Our computerized system of managing diabetic pregnancies was efficient, safe, and popular with our patients.

Keywords: Computer, diabetes, pregnancy, telemetry. 


\section{Zusammenfassung}

Computergestïtztes und telemetrisches Management der diabetischen Schwangerschaft in Cambridge

Einleitung

Eine gute Stoffwechselführung kann die Prognose einer diabetischen Schwangerschaft praktisch bis zum Grade einer normalen Schwangerschaft verbessern.

\section{Methode}

Um die Qualität unserer Vorsorge zu optimieren, bedienten wir uns bei unserer computergestützten Behandlung von 17 insulinabhängigen diabetischen Schwangeren des Ames Memory Glucometers. Dabei setzten wir für den Blutzucker einen Zielbereich von 3.5 bis 7.0 $\mathrm{mmol} / \mathrm{l}$ an. Die Patienten wurden in wöchentlichen oder 14-tägigen Abständen vom Diabetologen oder Geburtshelfer in einer gemeinsamen Klinik untersucht, wenn die Insulindosis eingestellt wurde; der HbA1 wurde in 4wöchigen Abständen gemessen. Ein telemetrisches System übermittelte über das öffentliche Telefonnetz die Blutzuckerdaten von den Wohnungen der Patienten zur Klinik.

\section{Ergebnisse}

Im Durchschnitt bestimmten unsere Patienten ihren eigenen Blutzuckerspiegel $4.5 \pm 1.2(\mathrm{SD})$ mal täglich. 6 Patienten übermittelten insgesamt 42-mal ihre Meßergebnisse telemetrisch von ihrer Wohnung aus. Unser computergesteuertes diabetisches Management-System versetzte uns in die Lage, bei 12 Patientinnen während des 3. Trimesters optimale Blutzuckerwerte und bei allen 17 Patientinnen für die gesamte Dauer der Schwangerschaft normale HbA1-Werte zu erzielen. Die durchschnittlichen Blutzuckerwerte waren $6.4 \pm 0.9 \mathrm{mmol} / 1$ im 1. Trimester, $5.9 \pm 1.2 \mathrm{mmol} / 1 \mathrm{im} \mathrm{2}$. Trimester und $5.4 \pm 1.0 \mathrm{mmol} / 1 \mathrm{im} \mathrm{3}$. Trimester. Die entsprechenden Werte für HbA1 lauten $8.0 \pm 1.5 \%, 6.5 \pm 0.8 \%$ und $6.2 \pm 0.4 \%$. Die weniger kooperativen Frauen, die weniger als die empfohlenen täglichen 5 Blutzuckermessungen durchführten, hatten signifikant höhere Werte als die kooperativen Frauen $(7.1 \mathrm{mmol} / \mathrm{l}$ vs. $5.2 \mathrm{mmol} / \mathrm{l})$. Der durchschnittliche Insulinbedarf verdoppelte sich während der Schwangerschaft, fiel jedoch 1 Woche nach der Entbindung zurück auf $74 \%$ der Dosis vor der Schwangerschaft; 6 Wochen nach der Entbindung betrug der Insulinbedarf lediglich $84 \%$ der Dosis vor der Schwangerschaft. Das durchschnittliche Gestationsalter betrug bei der Geburt $38.9 \pm 1.3$ Wochen, und wir hatten keine perinatalen Todesfälle. Zwei Babies waren makrosom, obwohl ihre Mütter unter guter diabetischer Kontrolle gestanden hatten. Vier Kinder wurden durch Kaiserschnitt geboren. Jedoch konnten wir in 93\% der geplanten Vaginalgeburten einen Erfolg erzielen.

\section{Diskussion}

Das Ames Memory Glucometer System liefert eine genaue und vollständige Aufzeichnung von in zeitlicher Folge erhobenen Blutzuckerwerten; während die vom Mikrocomputer zur Verfügung gestellte Analyse dem Kliniker bei seinem diabetischen Management hilft. Das Projekt „Überwachung zu Hause“ ist abhängig von sehr genauer Erfassung der Blutzuckerwerte, die, selbst erhoben, ohne Computeraufzeichnung bekanntlich unzuverlässig sind. Ein weiterer Vorteil dieses Systems bestand darin, daß es durch den Einsatz seiner übersichtlichen graphischen Darstellung der Blutzuckerdaten zur Schulung des Patienten verwandt werden konnte. Wir fanden heraus, daß, wenn das System in diesem Sinne eingesetzt wurde, 14 von 17 Patientinnen ein gesteigertes Selbstvertrauen in ihre Behandlung zeigten. Hypoglykämie ist eine unvermeidliche Konsequenz strenger diabetischer Kontrolle, und wir raten an, daß die Ehegatten in der Technik der intramuskulären Injektion von Glukagon unterwiesen werden sollten.

\section{Schluifolgerung}

Das computergesteuerte Management diabetischer Schwangerschaften, welches wir in Cambridge praktizieren, ist effizient, sicher und bei unseren Patienten beliebt.

Schlüsselwörter: Computer, Diabetes, Schwangerschaft, Telemetrie.

\section{Résumé}

Prise en charge informatisée et avec usage de la télémétrie de la grossesse chez la diabétique à Cambridge

Introduction

Un bon contrôle métabolique peut améliorer le pronostic de la grossesse chez la diabétique, en le rendant virtuellement identique à celui d'une grossesse normale.

\section{Méthode}

Afin d'optimiser la qualité de nos soins, nous avons utilisé le glucomètre à mémoire AMES, pour notre prise en charge informatisée de $\mathbf{1 7}$ grossesses chez des diabétiques insulino-dépendantes. Nous avons visé une cible pour la glycémie de 3,5 à $7,0 \mathrm{mmol} / 1$. Les patientes étaient vues en une consultation commune par le dia- bétologue et l'obstétricien chaque semaine ou toutes les 2 semaines lors des ajustements de l'insuline; l' $\mathrm{HbA}_{1} \mathrm{a}$ été mesuré toutes les 4 semaines. On a utilisé un système télémétrique pour transmettre les données de la glycémie du domicile des patientes à l'hopital en se servant du réseau téléphonique public.

\section{Résultats}

En moyenne, nos patientes mesurent leur propre glycémie à 4,5 $\pm 1,2$ (DS) reprises chaque jour. Six parmi ces patientes ont transmis les résultats de leur glycémie par télémétrie de leur domicile à 42 reprises au total. En utilisant notre système informatique de prise en charge du diabète, nous avons été capables d'obtenir des taux 
de glycémie optimaux au cours du troisième trimestre chez 12 patientes, et des taux normaux d' $\mathrm{HbA}_{1}$ chez l'ensemble de ces grossesses. Les taux moyens de glycémie étaient de $6,4 \pm 0,9 \mathrm{mmol} / 1$ au premier trimestre, $5,9 \pm \mathrm{wp} 1,2 \mathrm{mmol} / 1$ au second trimestre, et $5,4 \pm \mathrm{wp} 1,0$ $\mathrm{mmol} / \mathrm{l}$ au troisième trimestre. Les valeurs correspondantes de $l^{\prime} \mathrm{HbA}_{1}$ étaient de $8,0 \pm 1,5 \%, 6,5 \pm 0,8 \%$ et $6,2 \pm 0,4 \%$, respectivement. Les femmes peu complaisantes, qui ont réalisé moins de cinq glycémies recommandées chaque jour, ont eu des valeurs significativement plus sélevées que les patientes coopérantes $(7,1$ $\mathrm{mmol} / \mathrm{l}$ vs $5,2 \mathrm{mmol} / \mathrm{l})$. Les doses moyennes d'insuline sont doublées pendant la grossesse, mais ont chuté à $74 \%$ des doses d'avant la grossesse une semaine après l'accouchement; six semaines après l'accouchement les doses d'insuline étaient encore seulement à $84 \%$ des doses d'avant la grossesse. L'âge gestationnel moyen à la naissance a été de 38,9 $\pm 1,3$ semaines, et il n'y a pas eu de morts périnatales. Deux des enfants étaient macrosomes, bien que leurs mères aient eu un bon contrôle de leur diabète. Quatre patientes ont eu une césarienne, mais nous avons obtenu $93 \%$ d'accouchements par voie basse parmi les patientes chez lesquelles un accouchement par voie basse avait été prévu.

\section{Discussion}

Le glucomètre à mémoire AMES assure un enregistrement complet et approprié des glycémies programmées tandis que l'analyse fournie par le microordinateur aide le clinicien dans sa prise en charge du diabète. L'approche de la prise en charge à domicile dépend de lectures appropriées de la glycémie, mais on sait que la communication personnelle n'est pas fiable en l'absence d'enregistrements informatisés. Un avantage supplémentaire de ce système est qu'il peut être utilisé pour l'éducation des patientes, en faisant usage de l'affichage de graphiques lisibles des résultats de la glycémie. Utilisé de la sorte, nous avons trouvé que 14 des 17 femmes enceintes ont eu une confiance accrue dans leurs prises en charge. L'hypoglycémie est une conséquence inévitable d'un contrôle strict du diabète, et nous conseillons que les époux soient formés à la technique de l'injection intra-musculaire de glucagon.

\section{Conclusion}

Le système informatisé de prise en charge des grossesses diabétiques qui est actuellement utilisé à Cambridge est efficace sûr et populaire auprès de nos patientes.

Mots-clés: Diabète, grossesse, ordinateur, télémétrie.

Acknowledgements: We are grateful to Chris Moss, Judith Nicholls, and RichaRd BradFord for their help with this study. The format of figures 1 and 2 are the copyright of the Ames Division of Miles Inc. The terms Glucometer, Glucometer-M Dextrostix and Glucostix are trademarks of the Ames Division of Miles Inc.

\section{References}

[1] Alban Davies H, OM Edwards, KJ Dalton, J Nicholls: Computerized analysis of blood glucose data in diabetic pregnancy. In: DALTON KJ \& RDS FAWDRY (EDS) THE COMPUTER IN OBSTETRICS \& GyNAECOLOGY. IRL PRESS, OXFORd 1987

[2] Dalton KJ, AJ Dawson, NAJ Gough: Long distance telemetry of fetal heart rate from patients' homes using the public telephone network. Brit Med J 286 (1983) 1545

[3] Dalton KJ, JR CuRRIE: Fetal home telemetry made simple. J Obstet Gynecol 6 (1986) 151

[4] Dalton KJ, K Manning, PJ Robarts, JH Dripps, JR CURRIE: Computerized home telemetry of maternal blood pressure in hypertensive pregnancy. Int J Bio-Med Computing 21 (1987) 175

[5] Dalton KJ, H alban Davies, OM Edwards, J Nicholls, PJ RobarTs: Computerized home telemetry of maternal blood glucose levels in diabetic pregnancy. In: DALTON KJ \& RDS FAWDRY (eds) The Computer in Obstetrics \& Gynaecology. IRL Press, Oxford 1987
[6] Day JL, J Metcalfe, H Alban Davies: Evaluation of a new automatic recording system of diabetic patient information. Diabetologia 25 (1983) 149

[7] DruRy MI, AT Greene, JM Stronge: Pregnancy complicated by clinical diabetes mellitus: A study of 600 pregnancies. Obstet Gynecol 49 (1977) 519

[8] Fuhrmann K, H Reicher, K Semmler, F Fischer, M FISCHER, E GLOCKNER: Prevention of congential malformations in infants insulin-dependent diabetic mothers. Diabetes Care 6 (1983) 219

[9] Heller SR, JM Lowe, IR JohnSON, PMS O'Brien, P Clarke, EM SymondS, RB TATTERSALl: Seven years experience of home management in pregnancy in women with insulin-dependent diabetes. Diabetic Med 1 (1984) 199

[10] KARLSSON K, I KJELlmer: The outcome of diabetic pregnancies in relation to the mother's blood sugar level. Am J Obstet Gynecol 112 (1972) 213

[11] KaTZ J, PJ GILL: Initial evaluation of an ambulatory system for home monitoring and transmission of uterine activity data. Obstet Gynecol 66 (1985) 2737 
[12] KNIGHT G, RC Worth, JD WARD: Macrosomy despite a well-controlled diabetic pregnancy. Lancet 2 (1983) 1431

[13] LANGer O, RS MAzze: Diabetes in pregnancy: Evaluating self-monitoring performance and glycemic control with memory-based reflectance meters. Am J Obstet Gynecol 155 (1986) 635

[14] Miller E, JW Hare, JP Cloherty, PJ DunN, RE Gleason, JS SOELDNER, JL KITZMILlER: Elevated maternal hemoglobin A1c in early pregnancy and major congenital anomalies in infants of diabetic mothers. New Eng J Med 304 (1981) 1331

[15] Murphy J, J Peters, P Morris, TM Hayes, JF PEARSON: Conservative management of pregnancy in diabetic women. Brit Med J 288 (1984) 1203
[16] O'Connell M, D Cregan, MI Drury: The reliability of home glucose monitoring: A prelim report. Diabetic Med 3 (1086) 580A

[17] Thomson AM, WZ Billewicz, FE Hytten: The assessment of fetal growth. J Obstet Gynecol Brit Cwlth 75 (1968) 903

Kevin J. Dalton, PhD, MRCOS

Perinatal Research Group

Dept. of Obstet. \& Gynaecology

University of Cambridge

Rosie Maternity Hospital

Cambridge, CB2 2SW

England 


\section{Schneider · Stroiñski}

\section{Comprehensive $B_{12}$ \\ Chemistry · Biochemistry · Nutrition Ecology $\cdot$ Medicine}

1987. $18 \mathrm{~cm}$ x $26 \mathrm{~cm}$. XII, 409 pages, numerous illustrations.

Hardcover. DM 290,-; approx. US \$160.00

ISBN $311008239 \mathrm{X}$

This book is addressed to clinicians and advanced students in different areas such as chemists, biochemists, pharmacologists, nutritionists, animal breeders, ecologists and marine biologists who wish to extract essential information on particular aspects of vitamin $\mathrm{B}_{12}$.

Most of the data presented are accompanied by references to the original literature and are preceded by a brief and comprehensive introduction.

Some techniques which at present are of interest to a wider group of researchers such as immobilization of vitamin $B_{12}$ on supports, methods of $B_{12}$ assay and biological or chemical synthesis of various $B_{12}$ analogues are described in detail.

\section{Contents in brief}

Historical outline - Nomenclature of Corrinoids - Chemistry of Cobalamin and Related Compounds - Biosynthesis of Vitamin $\mathrm{B}_{12}$. Purification and Estimation of Vitamin $B_{12}$. The Occurrence and Distribution of Corrinoids - Cobamide Dependent Enzymes · Non-Enzymatic Vitamin $B_{12}$ Binding Proteins in Man and Animals - Medical Aspects of Vitamin $B_{12}$. Index of Species - Subject Index

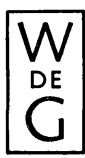

\section{de Gruyter - Berlin - New York}

